Inorganic Biochemistry

Elsevier Editorial System(tm) for Journal of

Manuscript Draft

Manuscript Number: JIB-16-0128R2

Title: Studies on DNA interaction of organotin(IV) complexes of meso tetra(4 sulfonatophenyl)porphine that show cellular activity

Article Type: SI: ISMEC 2015

Keywords: organometallic compounds; external binding; negative porphyrins; aggregation; viscosity

Corresponding Author: Prof. Tarita Biver, Ph. D.

Corresponding Author's Institution: University of Pisa

First Author: Sabriye Aydinoglu

Order of Authors: Sabriye Aydinoglu; Tarita Biver, Ph. D.; Stefania Figuccia; Tiziana Fiore; Sonia Montanaro; Claudia Pellerito

Abstract: The interaction of the diorgano- and triorganotin(IV) derivatives of meso-tetra-(4-sulfonatophenyl)porphine (Me2Sn)2TPPS, (Bu2Sn)2TPPS, (Me3Sn)4TPPS and (Bu3Sn)4TPPS to natural DNA was analysed (together with free meso-tetra-(4-sulfonatophenyl)porphine (H4TPPS) for comparison purposes). Particular attention was paid to (Bu3Sn) 4TPPS, a species that shows significant cellular action. Preliminary tests were done on the solution properties of the organotin(IV) compounds (pKA and possible self-aggregation). Spectrophotometric and spectrofluorometric experiments showed that all the investigated organotin(IV) derivatives strongly interact with DNA, the binding energy depending on the dye steric hindrance. In all cases experimental data concur in indicating that external binding mode prevails. Interestingly, fluorescence quenching and viscosity experiments show that the Bu-containing species, and in particular (Bu3Sn)4TPPS, are able to noticeably alter the DNA conformation. 
Ms. Ref. No.: JIB-16-0128

Title: Studies on DNA interaction of organotin(IV) complexes of meso tetra(4 sulfonatophenyl) porphine that show cellular activity

Dear Editor,

I send you the second revised version of the above quoted manuscript (JIB-16-0128).

The final suggestions of referee 3 have been duly taken into account, and the manuscript was changed and improved accordingly.

The reply to referee 3 is presented in the relevant "Response to Reviewers" file but is also, for your ease, attached below.

As for inclusion of this paper into the special issue devoted to ISMEC2015, I sure accept your kind offer. Just I hope that the final publication of this issue is near, as this work is now since some time under review...but this is not a big problem and I understand that the special issue is upcoming.

Best regards,

Tarita Biver

\section{Response to reviewer 3}

The reviewer is right saying that hydrophobic interactions between the butyl chains and the DNA helix are not strong enough to explain the strong affinity shown by the experiments.

A sentence was added as suggested indicating that: "for these reasons such calculations should be considered cautiously". Moreover, it has also to be noted that water molecules were not added into these very preliminary calculations; this also is now better explained and also for this reason calculations should be considered as indicative only.

In conclusion, the best model should consider a synergistic effect between phosphate affinity for tin, coupled with hydrophobic effects. The manuscript now more clearly proposes this explanation. To better enlighten the type and strength of the different contributions to overall binding, more detailed and reliable calculations could be envisaged. This is out of the scope of present paper, but can be an interesting prosecution of this work. This is also said in this revised version. 
Ms. Ref. No.: JIB-16-0128

Title: Studies on DNA interaction of organotin(IV) complexes of meso tetra(4 sulfonatophenyl) porphine that show cellular activity

\section{Reviewer \#3}

The reviewer is right saying that hydrophobic interactions between the butyl chains and the DNA helix are not strong enough to explain the strong affinity shown by the experiments.

A sentence was added as suggested indicating that: "for these reasons such calculations should be considered cautiously". Moreover, it has also to be noted that water molecules were not added into these very preliminary calculations; this also is now better explained and also for this reason calculations should be considered as indicative only.

In conclusion, the best model should consider a synergistic effect between phosphate affinity for tin, coupled with hydrophobic effects. The manuscript now more clearly proposes this explanation. To better enlighten the type and strength of the different contributions to overall binding, more detailed and reliable calculations could be envisaged. This is out of the scope of present paper, but can be an interesting prosecution of this work. This is also said in this revised version. 


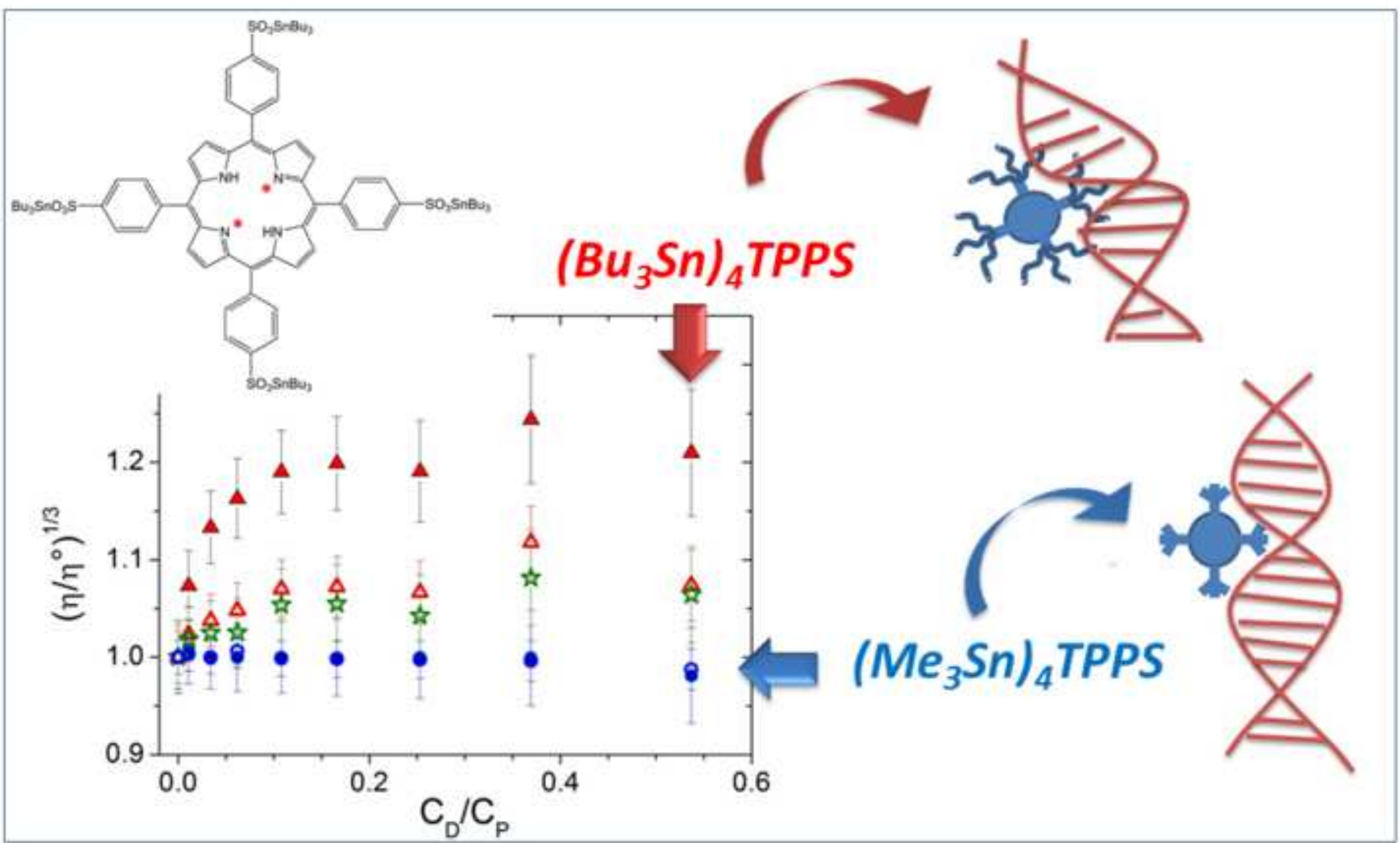




\section{SYNOPSIS FOR THE GRAPHICAL ABSTRACT}

Diorgano- and triorganotin(IV) derivatives of meso-tetra-(4-sulfonatophenyl)porphine interact with DNA and the butyl-containing species, known from literature to be endowed with significant cellular activity, are found to noticeably alter the DNA conformation. 


\section{$\underline{\text { HIGHLIGHTS }}$}

- Organotin substituents induce slight decrease of $\mathrm{pK}_{\mathrm{A}}$ of the central porphyrin ring

- Aggregation of the dyes on the DNA surface does occur for high dye content

- In excess of DNA the dyes monomers do bind DNA in external binding mode

- DNA conformation is altered upon binding

- The DNA modifications are more important in the presence of butyl residues 


\title{
Studies on DNA interaction of organotin(IV) complexes of meso-tetra(4-sulfonatophenyl)porphine that show cellular activity
}

\author{
Sabriye Aydinoglu ${ }^{\mathrm{a}}$, Tarita Biver ${ }^{*}, \mathrm{~b}$, Stefania Figuccia, ${ }^{\mathrm{b}}$ Tiziana Fiore ${ }^{\mathrm{c}}$, Sonia Montanaro ${ }^{\mathrm{b}}$, \\ Claudia Pellerito ${ }^{\mathrm{c}}$
}

\begin{abstract}
${ }^{a}$ Department of Analytical Chemistry, Faculty of Pharmacy, Cukurova University, 01330 Adana, Turkey; ${ }^{b}$ Dipartimento di Chimica e Chimica Industriale, Università di Pisa, Via Moruzzi 13, 56124 Pisa, Italy; ${ }^{\mathrm{c} D i p a r t i m e n t o ~ d i ~ F i s i c a ~ e ~}$ Chimica (DiFC), Università di Palermo, Viale delle Scienze, Ed. 17, 90128 Palermo, Italy.
\end{abstract}

*Corresponding Author: Tarita Biver, email tarita.biver@unipi.it, +39-050-2219259 


\begin{abstract}
The interaction of the diorgano- and triorganotin(IV) derivatives of meso-tetra-(4sulfonatophenyl)porphine $\left(\mathrm{Me}_{2} \mathrm{Sn}\right)_{2} \mathrm{TPPS},\left(\mathrm{Bu}_{2} \mathrm{Sn}\right)_{2} \mathrm{TPPS},\left(\mathrm{Me}_{3} \mathrm{Sn}\right)_{4} \mathrm{TPPS}$ and $\left(\mathrm{Bu}_{3} \mathrm{Sn}\right)_{4} \mathrm{TPPS}$ to natural DNA was analysed (together with free meso-tetra-(4-sulfonatophenyl)porphine (TPPS ${ }^{4-}$ ) for comparison purposes). Particular attention was paid to $\left(\mathrm{Bu}_{3} \mathrm{Sn}\right)_{4} \mathrm{TPPS}$, a species that shows significant cellular action. Preliminary tests were done on the solution properties of the organotin(IV) compounds $\left(\mathrm{pK}_{\mathrm{A}}\right.$ and possible self-aggregation). Spectrophotometric and spectrofluorometric experiments showed that all the investigated organotin(IV) derivatives strongly interact with DNA, the binding energy depending on the dye steric hindrance. In all cases experimental data concur in indicating that external binding mode prevails. Interestingly, fluorescence quenching and viscosity experiments show that the Bu-containing species, and in particular $\left(\mathrm{Bu}_{3} \mathrm{Sn}\right)_{4}$ TPPS, are able to noticeably alter the DNA conformation.
\end{abstract}

KEYWORDS: organometallic compounds, external binding, negative porphyrins, aggregation, viscosity, aggregation 


\section{Introduction}

Porphyrins and porphyrin-based pigments are molecules known since very long time but that are still object of very high interest in cutting-edge research [1-5]. Sulphonatophenyl porphyrins are used as catalysts [6] and photo-catalysts [7], as sensors for analytical purposes [8,9] and in photodynamic therapy [10-12]. Anionic sulphonatophenyl porphyrins can, despite their charge, bind DNA [9, 13] and are selective G-quadruplex binders with important applications in studies on telomerase inhibition [14], differently from the cationic ones [15].

Organotin complexes with a variety of ligands show interesting anti-tumour activity [16, 17]. Gielen and co-workers analysed several organotin systems; for instance, they found that pyridinecarboxylate-diethyl- and dibutyl-tin compounds are active against a colon carcinoma cell line at $10^{-7}$ M, better than cis-platin and doxorubicin; the ligand connected to the tin centre plays a role as butyl derivatives are more active than ethyl-ones [18]. More recent studies on diorganotin(IV) complexes of general formula $\mathrm{R}_{2} \mathrm{SnL}(\mathrm{R}=\mathrm{Me}, \mathrm{Bu}$ or $\mathrm{Ph}$ ) with tridentate ONO donor Schiff base also suggest that tin organometallic complexes can be candidates for cancer chemotherapeutics: again the $\mathrm{Bu}$ species is the most effective (already at $10^{-6} \mathrm{M}$ drug) against U373MG (CNS), PC3 (prostrate), Hop62 (lung), HL60 (leukemia), HCT15 (colon), SK-OV-3 (ovarian), HeLa (cervix) and MCF7 (breast) cancer cell lines with GI50 values $<10 \mu \mathrm{g} / \mathrm{ml}[19]$.

In this paper, we deal with systems that merge together the properties of the porphyrin ring and $\mathrm{Sn}(\mathrm{IV})$ metal centres, as well as inspecting the possible effect of methyl- or butyl-substituents.

The majority of the papers on metal-porphyrin systems concern the coordination of the metal ion by the porphyrin ring core. However, it was observed that organometallic porphyrin systems, where the $\mathrm{Sn}(\mathrm{IV})$ residue is coordinated to the central ring via side chains or sulphate groups, show interesting and peculiar in vitro activity [17, 20-24]. Dibutyltin(IV) porphinate complexes based on the tris(pyridinyl)porphyrin moiety were found to be strongly active against human A-549 tumour and P388 leukaemia cells at concentrations lower than $10^{-6} \mathrm{M}$; the effect was related not to DNA 
cleavage (negative plasmid DNA tests) but to very high affinity to the nucleic acid [24]. Tin(IV)[meso-tetra(4-carboxyphenyl)porphinate] derivatives are effective against fibroblast growth at $2.5 \times 10^{-7} \mathrm{M}$ but no evidence was found for plasmid DNA cleavage by the compounds at molar ratios as high as 1:10 drug/DNA base pairs $[25,26]$.

With particular regard to the here analysed sulfonatophenyl species, it has been shown that dibutyltin(IV) and tributyltin(IV) derivatives of meso-tetra-(4-sulfonatophenyl)porphine are cytotoxic and induce apoptosis in A375 human melanoma cells already at $10^{-7} \mathrm{M}$ concentration [20$23,27]$. DNA fragmentation analysis, flow cytometry tests as well as caspases activation analysis by Western blot were carried out; A375 cells undergo internucleosomal DNA fragmentation induced by the drugs [21]. Both the dibutyl- and tributyltin(IV) compounds activate caspase- 8 and caspase-9 leading to caspase-3 activation, suggesting that these two porphyrin derivatives lead to the apoptosis of human melanoma cells via both death receptor-mediated and mitochondrial apoptotic pathways. Western blotting experiments on activated protein kinases suggest that the MAP kinases are involved in the apoptotic death of A375-treated cells [22].

Despite the above described studies on cellular activity of the target compounds, some detailed inspection of their binding to natural DNA was still missing. Therefore, to go on enlightening the possible mechanism of action of these sulphonatophenyl-organometallic complexes and in the frame of our mechanistic studies on small molecules binding to nucleic acids, we have analysed the details of interaction of the diorganotin(IV) and triorganotin(IV) derivatives of meso-tetra-(4sulfonatophenyl)porphine to natural DNA. Free meso-tetra-(4-sulfonatophenyl)porphine was also tested by same experiments for comparison purposes.

\section{Materials and methods}

Materials Water soluble free meso-tetra(4-sulfonatophenyl)porphine (TPPS ${ }^{4-}$ ) was purchased from Porphyrin Products (Logan, UT, USA). Four organotin(IV) derivatives of this ligand were studied: 
$\left(\mathrm{Me}_{2} \mathrm{Sn}\right)_{2}$ TPPS, $\left(\mathrm{Bu}_{2} \mathrm{Sn}\right)_{2}$ TPPS, $\left(\mathrm{Me}_{3} \mathrm{Sn}\right)_{4}$ TPPS and $\left(\mathrm{Bu}_{3} \mathrm{Sn}\right)_{4}$ TPPS $(\mathrm{Me}=$ methyl, $\mathrm{Bu}=$ butyl $)$. These organometallic complexes were obtained and purified according to the already described procedure [20]. Stock solutions of the porphyrin dyes (ca. $2 \times 10^{-3} \mathrm{M}$ ) were prepared by dissolving weighted amounts of the solid in dimethyl sulfoxide (DMSO, Carlo Erba, purity $\geq 99.5 \%$ ). Note that in the solid state these complexes polymerize owing to formation of sulphonato bridges; however, it is also found that in DMSO solution these bridges are broken and the polymeric structure collapses to monomers, due to the presence of coordinated DMSO molecules in the tin coordination sphere [27]. Working solutions were obtained by dilution of the stocks (using a pH 7.0 working buffer in ultra-pure MilliQ water, see below). In the case of viscometric experiments the solid was directly dissolved in the buffer to avoid even minimal errors due to changes in the DMSO content. In fact, as in this experiment $C_{D} / C_{P}=0$ to 0.6 , use of a DMSO dye stock will change the DMSO content from 0 to ca. $1 \%$ and it was found (not shown) that even this small variation could non-negligibly affect the measured viscosity. Solutions were kept in the dark at $4^{\circ} \mathrm{C}$ and used within two days; the molar concentration of the dye is indicated as $C_{D}$. Calf thymus DNA (DNA) was purchased from Sigma-Aldrich in the form of lyophilised sodium salt, dissolved into water and sonicated to reduce the polynucleotide length (to ca. 800 base pairs) [28]. Stock solutions were standardised spectrophotometrically, using $\varepsilon=13,200 \mathrm{M}^{-1} \mathrm{~cm}^{-1}$ at $260 \mathrm{~nm}, 0.1 \mathrm{M}(\mathrm{NaCl}), \mathrm{pH}=7.0$ [27]. The DNA molar concentration (expressed in base pairs) is indicated as $C_{P}$. The working DNA solutions were kept at $4^{\circ} \mathrm{C}$ and used within a week. All dye and polynucleotide working solutions were kept at $\mathrm{pH}=7.0$ using a $0.01 \mathrm{M}$ Sodium Cacodylate buffer $\left(\mathrm{NaCac}=\left(\mathrm{CH}_{3}\right)_{2} \mathrm{AsO}_{2} \mathrm{Na}\right.$, analytical grade salt from Sigma). The ionic strength (I) was adjusted using $\mathrm{NaCl}$ (analytical grade salt from Sigma). All other reagents were the analytic grade forms by Sigma and were used as received.

Methods The $\mathrm{pH}$ measurements were done using a Metrohm $\mathrm{pH}-$ meter. The spectrophotometric measurements have been done using a Shimadzu UV2450 double beam spectrophotometer with 
temperature control to within $\pm 0.1^{\circ} \mathrm{C}$. The fluorescence measurements were performed using a Perkin Elmer LS55 spectrofluorometer with temperature control to within $\pm 0.1^{\circ} \mathrm{C}$. In the fluorescence quenching measurements, increasing amounts of a buffer solution containing the quencher NaI, are added directly in the cell $(1 \mathrm{~cm}$ path length) which contains a known volume of the dye solution (typically ca. $0.3 \mu \mathrm{M}$, also buffered). The same procedure was adopted in the DNA/porphyrin titrations. Here, increasing amounts of DNA are added to the dye solution (typically ca. $0.3 \mu \mathrm{M})$ directly in the cell $(1 \mathrm{~cm}$ path length). The additions were in all cases made using a Hamilton syringe connected to a micrometric screw that enabled volumes as small as $0.166 \mu \mathrm{L}$ to be added. Absorbance titrations were analysed at $\lambda=413 \mathrm{~nm}$. Viscosity measurements were performed on an Ubbelodhe micro-viscometer immersed in a thermostatted water-bath at 40.0 $\pm 0.1^{\circ} \mathrm{C}$. The flow time was measured with a digital stopwatch; the values shown are averaged over at least triplicated measurements. The data were analysed by means of non-linear least-square fitting procedures performed by a JANDEL (AISN software) program or by means of the HypSpec14 software (Hyperquad UK). Some preliminary theoretical geometry optimization calculations (in vacuo) were made by means of the Hyperchem 7.02 package.

\section{Results and Discussion}

Dyes $p K_{A}$ and auto-aggregation features The nitrogen atoms inside the macrocyclic pyrrole ring of porphyrin dyes can be protonated, the peripheral substituents strongly influencing the core acid dissociation constant $\left(\mathrm{pK}_{\mathrm{A}}\right)$ [29]. The $\mathrm{pK}_{\mathrm{A}}$ of TPPS ${ }^{4-},\left(\mathrm{Me}_{2} \mathrm{Sn}\right)_{2}$ TPPS and $\left(\mathrm{Bu}_{3} \mathrm{Sn}\right)_{4}$ TPPS (Fig. 1) were measured by means of UV-vis titrations.

$<$ Fig. 1 near here >

Fig. 2A shows the variations of the absorbance bands of $\left(\mathrm{Bu}_{3} \mathrm{Sn}\right)_{4}$ TPPS upon addition of increasing amounts of $\mathrm{HCl}$. Very significant changes occur in the major (Soret) band of the dye that shifts 
from $413 \mathrm{~nm}$ up to $435 \mathrm{~nm}$ upon acidification. As for the minor Q bands, before addition of acid the dye displays four bands centred respectively at ca. $515 \mathrm{~nm}, 552 \mathrm{~nm}, 581 \mathrm{~nm}$ and $634 \mathrm{~nm}$; by lowering $\mathrm{pH}$, the last one becomes predominant and exhibits a red shift to $646 \mathrm{~nm}$ (inset). The variation of absorbance at $435 \mathrm{~nm}$ as a function of the acid content yields the binding isotherm shown in Fig. 2B. Analysis of the spectra using the HypSpec14 software shows that the two $\mathrm{pK}_{\mathrm{A}} \mathrm{S}$ for the protonation of the immine-nitrogen atoms of the inner ring are indistinguishable and $\mathrm{pK}_{\mathrm{A} 1}=$ $\mathrm{pK}_{\mathrm{A} 2}=4.05 \pm 0.02$ (relevant system speciation is shown as inset in Fig. $2 \mathrm{~B}$ ). The same analysis yields for $\left(\mathrm{Me}_{2} \mathrm{Sn}\right)_{2} \mathrm{TPPS} \mathrm{pK}_{\mathrm{A} 1}=\mathrm{pK}_{\mathrm{A} 2}=4.14 \pm 0.02$ and for $\mathrm{TPPS}^{4-} \mathrm{pK}_{\mathrm{A} 1}=\mathrm{pK}_{\mathrm{A} 2}=4.24 \pm 0.02$ (respectively Fig. S1 and Fig. S2 of the Supplementary Information). Note that, in agreement with general observations on similar systems, the peripheral groups have significant effect on the acidity and basicity of the porphyrin and, more particularly, of the pyrrole nitrogens: electron donating residuals lead to a lowering of the acidity (higher $\mathrm{pK}_{\mathrm{A}}$ ) [29].

< Fig. 2 near here >

Concerning the dye aggregation process, literature data show that in acidic media the protonated form of TPPS $^{4-}\left(\mathrm{H}_{2}\right.$ TPPS $\left.^{2-}\right)$ undergoes auto-aggregation phenomena in the form of staggered, sideby-side (J-type) assemblies [30-33] but only limited information is available about self-aggregation of sulphonato-porphyrins at physiological $\mathrm{pH}[29,30,34]$. This aspect is, on the other hand, interesting for our studies on interactions with DNA. To analyse potential self-aggregation at $\mathrm{pH}$ 7.0, we have registered UV-vis and fluorescence emission spectra of increasing amounts of TPPS ${ }^{4-}$, $\left(\mathrm{Me}_{2} \mathrm{Sn}\right)_{2} \mathrm{TPPS}$ and $\left(\mathrm{Bu}_{3} \mathrm{Sn}\right)_{4} \mathrm{TPPS}$ dyes. Fig. 3A shows the absorbance spectra of $\left(\mathrm{Bu}_{3} \mathrm{Sn}\right)_{4} \mathrm{TPPS}$ solutions at different dye concentrations at $\mathrm{pH} 7.0(\mathrm{NaCl} 0.1 \mathrm{M}$ and $\mathrm{NaCac} 0.01 \mathrm{M})$. No born of new bands is observed (Fig. S3) by increasing dye concentration and the Beer's law is obeyed in the explored concentration range. Similar analyses on $\left(\mathrm{Me}_{2} \mathrm{Sn}\right)_{2} \mathrm{TPPS}$ and TPPS ${ }^{4-}$ are shown in Fig. S4 
and Fig. S5, respectively. This result indicates the absence of strong/extended aggregates formation. On the other hand, more in depth inspection of the data can be done by using the ratio $A_{0} / A_{1}$, where $A_{0}$ is the absorption at the maximum $(413 \mathrm{~nm})$ and $A_{1}$ that at a selected wavelength: a decrease in the $A_{0} / A_{1}$ value is considered indicative of an aggregation process [35]. Fig. 3B shows that some, although limited, self-aggregation process seems to take place for $\left(\mathrm{Me}_{2} \mathrm{Sn}\right)_{2} \mathrm{TPPS}$ and TPPS ${ }^{4-}$. The aggregate signal is blue-shifted respect to main monomer band $\left(\mathrm{A}_{1}<\mathrm{A}_{0}\right)$, this behaviour suggesting that these species undergo slight $\mathrm{H}$-aggregation [36]. On the other hand, a significantly smoother decreasing trend is displayed by $\left(\mathrm{Bu}_{3} \mathrm{Sn}\right)_{4} \mathrm{TPPS}$, in agreement with the higher steric hindrance of this species. The latter result agrees with previous findings [27].

$<$ Fig. 3 near here >

Fluorescence excitation/emission 3D plots of $\left(\mathrm{Bu}_{3} \mathrm{Sn}\right)_{4} \mathrm{TPPS},\left(\mathrm{Me}_{2} \mathrm{Sn}\right)_{2} \mathrm{TPPS}$ and $\mathrm{TPPS}^{4-}$ and emission spectra for increasing dye concentrations are shown in Figs. S6, S7 and S8 respectively. The maximum of fluorescence emission is always centred at ca. $641 \mathrm{~nm}\left(\lambda_{\mathrm{ex}}=410 \mathrm{~nm}\right)$. No changes of the emission band are observed for high dye contents, corroborating the idea that any aggregation is neither extended nor strong.

On the whole, the obtained results indicate that the presence of the organotin(IV) residues negligibly affects their photophysical properties (absorbance and fluorescence), as these are driven by the common central core. On the other hand, bulky peripheral substituents (obviously) oppose to some, although modest, aggregation. Note that literature data confirm that limited aggregation occurs for anionic porphyrin even at neutral $\mathrm{pH}$ [29]. More interestingly, as for the protonation, the organotin residues influence the $\mathrm{pK}_{\mathrm{A}}$ by lowering it. Pasternack and co-workers demonstrated that a two-step protonation path might be active $\left(\mathrm{pK}_{\mathrm{A} 1}\right.$ and $\left.\mathrm{pK}_{\mathrm{A} 2}\right)$, each corresponding to the $\mathrm{H}^{+}$addition to one of the nitrogen atoms [37]. On the other hand, for some systems, the two equilibria are so close each other to become undistinguishable $[31,38]$. For the here analysed systems the non-well 
defined isosbestic point (Fig. 2A) agrees with non-simple equilibrium (i.e. more than two species); however, these systems fall in the latter case and a unique $\mathrm{pK}_{\mathrm{A}}$ could be calculated.

DNA binding The interaction with DNA of the four $\left(\mathrm{Me}_{2} \mathrm{Sn}\right)_{2} \mathrm{TPPS},\left(\mathrm{Bu} \mathrm{L}_{2} \mathrm{Sn}\right)_{2} \mathrm{TPPS}$, $\left(\mathrm{Me}_{3} \mathrm{Sn}\right)_{4} \mathrm{TPPS}$ and $\left(\mathrm{Bu}_{3} \mathrm{Sn}\right)_{4} \mathrm{TPPS}$ organometallic derivatives, plus the $\mathrm{TPPS}^{4-}$ reference, was analysed by spectrophotometry and spectrofluorometry. The low concentrations used in these studies ensure that the dyes are present only in the monomeric form. Note that the concentration used agrees with that found to be active in the cellular tests (see Introduction paragraph). Fluorescence data show, upon DNA polynucleotide addition, significant variation of the emission features. Fig. 4 shows the relevant spectra and the corresponding binding isotherm for the $\left(\mathrm{Bu}_{3} \mathrm{Sn}\right)_{4}$ TPPS/DNA system (similar results are obtained for the other systems, see Fig. S9). The spectral behaviour and the binding isotherms suggest that the organotin dyes indeed bind DNA with high affinity. However, further analysis of the different dye/DNA systems revealed low reproducibility of the data, possibly related to some photo-bleaching by the powerful lamp of the spectrofluorometer during the relatively long titration times. Therefore, absorbance measurements were preferred for the inspection of the details of DNA binding (see below). The less powerful spectrophotometer lamp was not found to produce bleaching effects in a significant extent.

\section{< Fig. 4 near here >}

Absorbance spectra recorded at $25^{\circ} \mathrm{C}$ upon addition of increasing amounts of DNA to the dye solution for the $\left(\mathrm{Bu}_{3} \mathrm{Sn}\right)_{4}$ TPPS/DNA system are shown in Fig. 5A and the relevant binding isotherm is given in Fig. 5B. The spectral behaviour observed is qualitatively the same for all TPPS ${ }^{4-} / \mathrm{DNA}$, $\left(\mathrm{Me}_{2} \mathrm{Sn}\right)_{2} \mathrm{TPPS} / \mathrm{DNA}, \quad\left(\mathrm{Bu}_{2} \mathrm{Sn}\right)_{2} \mathrm{TPPS} / \mathrm{DNA}, \quad\left(\mathrm{Me}_{3} \mathrm{Sn}\right)_{4} \mathrm{TPPS} / \mathrm{DNA} \quad$ (Fig. $\left.\quad \mathrm{S} 10\right)$ and $\left(\mathrm{Bu}_{3} \mathrm{Sn}\right)_{4} \mathrm{TPPS} / \mathrm{DNA}$ titrations, and this is maintained also when temperature increased to $40{ }^{\circ} \mathrm{C}$ (Fig. S11). 


\section{$<$ Fig. 5 near here >}

The spectral variations induced by DNA addition are not dramatic. However, formation of the dye/DNA complex is confirmed by an isosbestic point at ca. $420 \mathrm{~nm}$ (constant for all systems) and a hypochromic effect. Upon polynucleotide binding a shoulder, located near $395 \mathrm{~nm}$, tends to disappear, while spectral broadening towards higher wavelengths occurs (bathochromic effect). DNA interaction of dyes often drives their aggregation on the polynucleotide surface [39]; in this case the first effect can be related to the disruption of some dye aggregation on the polynucleotide (that forms at the beginning of titration i.e. dye excess respect to polymer) upon dilution over increasing DNA sites [39]. Both hypochromic and bathochromic effects are often related to an intercalative mode of interaction [40, 41]. However, total intercalation in general and porphyrin dyes intercalation in DNA usually produce significant red shifts [40, 42]. In this case the small changes in the spectra would suggest major contribution of external binding.

The interaction between a DNA reacting site (base pair, P) and the porphyrin dye (D) to give the complex (PD) can be described by a simplified 1:1 reaction model (reaction (1))

$$
\mathrm{P}+\mathrm{D} \leftrightarrows \mathrm{PD}
$$

The evaluation of the binding constant for reaction (1), K, can be done by analysing the spectrophotometric data using equation (2)

$\frac{C_{D}}{\Delta A}=\frac{1}{K \Delta \varepsilon} \times \frac{1}{[P]}+\frac{1}{\Delta \varepsilon}$

where $C_{D}$ is the total analytical dye concentration, $\Delta A=A-A_{0}, A_{0}$ is the absorbance in the absence of DNA, $[\mathrm{P}]$ is the concentration of DNA free sites $\left([\mathrm{P}]=\mathrm{C}_{\mathrm{P}}-[\mathrm{PD}]\right)$ and $\Delta \varepsilon=\varepsilon_{\mathrm{PD}}-\varepsilon_{\mathrm{D}}$ is the variation of the optical parameters upon binding [43-45]. According to equation (2) a plot of $\mathrm{C}_{\mathrm{D}} / \Delta \mathrm{A}$ vs. $1 /[\mathrm{P}]$ should yield a straight line with $\Delta \varepsilon=1 /$ intercept and $\mathrm{K}=$ intercept/slope. Note that the calculus requires an iterative procedure where, in a first approximation $[\mathrm{P}]=\mathrm{C}_{\mathrm{P}}$ so to obtain a first 
$\mathrm{K}$ evaluation. This is used to obtain $[\mathrm{P}]$, replot the data to yield a better $\mathrm{K}$ estimation, and so on until convergence is reached. Fig. 6 shows an example of data analysis.

< Fig. 6 near here >

Fig. 6 suggests that the simplified 1:1 model is insufficient to describe the behaviour of the system under conditions of high 1/[P] (i.e. low DNA content) as the expected linear trend is not obeyed. On the other hand, the model seems to apply at low 1/[P] (i.e. high DNA, thus end of titration). This behaviour agrees with the spectral analysis above and is typical of external binding systems where high dye crowding on the polynucleotide surface at $C_{D} \gg C_{P}$ produce complicate cooperative effects so that model (1) does not correspond to the real system. As $C_{P}$ is increased, dye dilution over high number of DNA sites enables single binding at an isolated site, according to reaction (1). This seems to be the case for $\left(\mathrm{Bu}_{2} \mathrm{Sn}\right)_{2}$ TPPS/DNA, $\left(\mathrm{Bu}_{3} \mathrm{Sn}\right)_{4}$ TPPS/DNA (Fig. 6) and also the other organotin(IV)/DNA systems that show similar behaviour (Fig. S12). It has already been observed that anionic porphyrin and TPPS ${ }^{4-}$ itself can bind to DNA externally [46] and, under conditions of high dye concentration, form J-aggregates [47]. Table 1 collects the results of data analyses according to equation (2) relevant to the very first part of the graphs (final part of titration, high $\mathrm{C}_{\mathrm{P}}$ ).

In some cases the binding turned to be quantitative (both a $25^{\circ} \mathrm{C}$ and $40{ }^{\circ} \mathrm{C}$ ), with no convergence of the iterative procedure. In general, the binding constant values found are very high. This occurs despite the negative charge very likely borne by the planar aromatic dyes. Note that previous studies have shown that hydrolytic species (and in particular for $(\mathrm{Bu} 3 \mathrm{Sn})_{4} \mathrm{TPPS},\left[\left(\mathrm{Bu} \mathrm{Sn}_{3}\right)_{4} \mathrm{TPPS}(\mathrm{OH})_{4}\right]^{4-}$ ) are present under physiological conditions [27]. This result suggests that for these systems the main driving force for binding is connected to non-electrostatic interactions (hydrophobic, $\pi-\pi$ stacking). Moreover, it has also been found that Sn(IV) shows strong affinity towards phosphate groups because of its Lewis acidic properties so that $\mathrm{Sn}(\mathrm{IV})$-phosphate binding can occur [48]. Table 1 
shows that the binding affinities decrease by increasing the steric hindrance of the residues. Moreover, the binding parameters decrease by increasing temperature, indicating an exothermic process taking place. However, the sensitivity to temperature decreases in the order $\left(\mathrm{Bu}_{2} \mathrm{Sn}\right)_{2} \mathrm{TPPS} / \mathrm{DNA}>\left(\mathrm{Me}_{3} \mathrm{Sn}\right)_{4} \mathrm{TPPS} / \mathrm{DNA}>\left(\mathrm{Bu}_{3} \mathrm{Sn}\right)_{4} \mathrm{TPPS} / \mathrm{DNA}$. Just to better enlighten this latter behaviour from the data of Table 1, dependence of $\mathrm{K}$ on temperature can be analysed (as $\ln \mathrm{K}$ $=-\Delta \mathrm{H} / \mathrm{RT}+\Delta \mathrm{S} / \mathrm{R})$ providing rough estimates of $\Delta \mathrm{H}$ and $\Delta \mathrm{S}(\Delta \mathrm{H}$ and $\Delta \mathrm{S}$ supposed constant in the limited temperature range studied): both decrease as the steric hindrance increases (Fig. S13), indicating external binding modes [49].

Quenching experiments where performed to gain further information on the type of binding mode. Reduction of the effect of a quencher on a fluorescent dye is an indication of DNA shielding, i.e. of dye penetration into the polynucleotide [39]. Stern-Volmer plots (Fig. S14) were done on the organotin(IV) dyes alone and on their DNA mixtures (quencher iodide ion). Table 2 collects the data on the percentage of slope reduction in the presence of DNA. In all cases the quenching effect is very poorly affected by the presence of DNA, in agreement with external binding. On the other hand, Bu-containing dyes show the higher effects. This result could find an explanation in the light of the viscosity experiments described below.

Viscometric measurements have been done at constant DNA $\left(C_{P}=2.3 \times 10^{-4} \mathrm{M}\right)$ and varying the dye concentration in the $0.01<\mathrm{C}_{\mathrm{D}} / \mathrm{C}_{\mathrm{P}}<0.54$ range. Relative viscosity is calculated from equation (3).

$$
\frac{\eta}{\eta_{0}}=\frac{\mathrm{t}-\mathrm{t}_{\mathrm{solv}}}{\mathrm{t}_{\mathrm{DNA}}-\mathrm{t}_{\mathrm{solv}}}
$$

where $t, t_{\text {solv }}$ e $t_{\text {DNA }}$ denote respectively the flow time of the sample (dye/DNA mixture), the flow time of the solvent and the flow time of $2.3 \times 10^{-4} \mathrm{M}$ DNA. Data have been collected at $40{ }^{\circ} \mathrm{C}$. The results are shown in Fig. 7. 
< Fig. 7 near here >

The Bu-containing species induce significant DNA viscosity variation, the higher effect being observed for $\left(\mathrm{Bu}_{3} \mathrm{Sn}\right)_{4}$ TPPS. Groove binding by positively charged porphyrins bearing ammonium side chains do not produce this effect but, instead, slight decrease of ds-calf thymus-DNA viscosity [50]. It seems therefore that the Bu-organotin dyes, although binding to DNA externally, are able to induce non negligible effects on the DNA conformation strongly connected with the presence of the Bu-chain. Interestingly, these two species (and in particular $\left(\mathrm{Bu}_{3} \mathrm{Sn}\right)_{4} \mathrm{TPPS}$ ) are those that show more significant biological effects [20,21].

Energy minimisation calculations, done with the help of the HypChem software, for the binding between double stranded DNA and $\mathrm{CH}_{3}-\mathrm{Sn}-\mathrm{Me}_{2}, \mathrm{CH}_{3}-\mathrm{Sn}-\mathrm{Bu}_{2}, \mathrm{CH}_{3}-\mathrm{Sn}-\mathrm{Me}_{3}$ or $\mathrm{CH}_{3}-\mathrm{Sn}-\mathrm{Bu}_{3}$ species evidence the strong affinity of the butyl chains for the nucleic acid grooves. Therefore, it seems that hydrophobic interactions between butyl chains and DNA grooves also play a role. On the other hand, such hydrophobic interactions are not strong enough to explain the strong affinity shown by the experiments and these preliminary calculations in vacuo should be considered cautiously.

Conclusions The analysis of the solution features shows that organotin(IV) substituents induce a slight decrease of the $\mathrm{pK}_{\mathrm{A}}$ of the central porphyrin ring. Some limited H-aggregation of the less bulky species seems to be present also at neutral $\mathrm{pH}$. Aggregation of the dyes on the DNA surface does occur for $C_{D}>C_{P}$, but return to the monomer form of the dye could be observed in excess of DNA. The binding affinity of the investigated porphyrins for DNA is high and it can overcome charge repulsion between the external skeleton of the polymer and the dyes (forming $\mathrm{OH}^{-}$ coordinating species as $\left(\mathrm{Bu}_{3} \mathrm{Sn}\right)_{4}$ TPPS $\left(\mathrm{OH}^{-}\right)_{4}{ }^{4-}$ at $\mathrm{pH} 7.0$ [27]). The binding could have some very limited intercalation features, but these fade out in favour of external binding as the steric hindrance of the porphyrin is increased. Interestingly, despite external binding, in particular $\left(\mathrm{Bu}_{3} \mathrm{Sn}\right)_{4} \mathrm{TPPS}$ is 
able to significantly alter DNA viscosity. This result, together with fluorescence quenching data and some energy minimisation tests, suggest a groove binding mode where the porphyrin ring is still accessible to the solvent but hydrophobic butyl substituents strongly interact with the groove, modifying DNA conformation. Sn(IV)-phosphate can also occur [48] and this process would agree with high binding constants to DNA [24]. On the other hand, evidence for phosphate binding is, even if not exclusively [51], often related to organotin-systems containing good leaving groups as $\mathrm{Cl}^{-}$ligands $[52,53]$. In conclusion, the best model for interaction considers a synergistic effect between tin affinity for phosphates, coupled with hydrophobic effects. To better enlighten the type and strength of the different contributions to overall binding, more detailed theoretical calculations (out of the scope of present paper) can be envisaged in future investigations.

Given the results of previous cellular studies, DNA is likely not the primary target for these molecules [17], even if some authors proposed that DNA is the probable target for the cytotoxic activity [54]. On the other hand, surprisingly (because of charge and of steric hindrance), the studied porphyrins do strongly bind DNA and $\left(\mathrm{Bu}_{3} \mathrm{Sn}\right)_{4}$ TPPS is able to provoke important DNA conformational changes. The non-negligible contribution of hydrophobic effects modulated by the Bu-chains would agree with the finding that these drugs are able to significantly alter the cellular membrane $[17,26]$ and that their activity is related to a balance between their water solubility/availability [24] and lipophilic properties [55].

\section{List of abbreviations}

TPPS ${ }^{4-} \quad$ meso-tetra-(4-sulfonatophenyl)porphine

$\left(\mathrm{Me}_{2} \mathrm{Sn}\right)_{2} \mathrm{TPPS} \quad$ diorganotin(IV) methyl derivative of meso-tetra-(4-sulfonatophenyl)porphine

$\left(\mathrm{Me}_{3} \mathrm{Sn}\right)_{4} \mathrm{TPPS} \quad$ triorganotin(IV) methyl derivative of meso-tetra-(4-sulfonatophenyl)porphine

$\left(\mathrm{Bu}_{2} \mathrm{Sn}\right)_{2} \mathrm{TPPS} \quad$ diorganotin(IV) n-butyl derivative of meso-tetra-(4-sulfonatophenyl)porphine 
$\left(\mathrm{Me}_{2} \mathrm{Sn}\right)_{2} \mathrm{TPPS} \quad$ triorganotin(IV) n-butyl derivative of meso-tetra-(4-sulfonatophenyl)porphine

DNA sonicated double stranded DNA (ca. 800 base pairs) from calf thymus

DMSO dimethyl sulphoxide solvent

NaCac $\quad$ Sodium cacodylate/cacodylic acid buffer for $\mathrm{pH}=7.0$

Acknowledgements The financial support by PRA 2015 of the University of Pisa, project PRA_2015_0038, by Obra Social "la Caixa", project OSLC-2012-007, by the Ministerio de Economia y Competividad - Gobierno de España, project MINECO CTQ2014-58812-C2-2-R, and by Università degli Studi di Palermo Grant ORPA07SLXE are gratefully acknowledged. 


\section{REFERENCES}

[1] M.B. Ballatore, J.E. Durantini, N.S. Gsponer, M.B. Suarez, M.A. Gervaldo, L.A. Otero, M.B. Spesia, M.E. Milanesio, E.N. Durantini, Environ. Sci. Technol. 49 (2015) 7456-7463.

[2] Y. Zhao, Q. Shang, J. Yu, Y. Zhang, S. Liu, ACS Appl. Mater. Interfaces 7 (2015) 11783-11791.

[3] D.K. Deda, A. Budu, L.N. Cruz, K. Araki, C.R.S. Garcia, Mini-Rev. Med. Chem. 14 (2014) 1055-1071.

[4] F. Figueira, P.M.R. Pereira, S. Silva, J.A.S. Cavaleiro, J.P.C. Tome, Curr. Org. Synth. 11 (2014) 110-

126.

[5] A.S. Rury, T.E. Wiley, R.J. Sension, Acc. Chem. Res. 48 (2015) 860-867.

[6] S. Das, F. Alhasson, D. Dattaroy, S. Pourhoseini, R.K. Seth, M. Nagarkatti, P.S. Nagarkatti, G.A.

Michelotti, A.M. Diehl, B. Kalyanaraman, S. Chatterjee, Am. J. Pathol. 185 (2015) 1944-1957.

[7] R.W. Larsen, L. Wojtas, Dalton Trans. 44 (2015) 2959-2963.

[8] K. De Wael, A. Adriaens, E. Temmerman, Analytica Chimica Acta 554 (2005) 60-65.

[9] A.E. Holmes, J.K. Choi, J. Francis, A. D'Urso, M. Balaz, J. Inorg. Biochem. 110 (2012) 18-20.

[10] N.S. Gsponer, M.B. Spesia, E.N. Durantini, Photodiagnosis Photodyn. Ther. 12 (2015) 67-75.

[11] E. Feese, R.A. Ghiladi, J. Antimicrob. Chemother. 64 (2009) 782-785.

[12] M.P. Cormick, M.G. Alvarez, M. Rovera, E.N. Durantini, Eur. J. Med. Chem. 44 (2009) 1592-1599.

[13] J.K. Choi, A. D'Urso, M. Balaz, J. Inorg. Biochem. 127 (2013) 1-6.

[14] H. Yaku, T. Murashima, D. Miyoshi, N. Sugimoto, Molecules 17 (2012) 10586.

[15] S. Neidle, FEBS J. 277 (2010) 1118-1125.

[16] F. Arjmand, S. Parveen, S. Tabassum, C. Pettinari, Inorg. Chim. Acta 423 (2014) 26-37.

[17] C. Pellerito, L.s. Nagy, L. Pellerito, A. Szorcsik, J. Organomet. Chem. 691 (2006) 1733-1747.

[18] M. Gielen, A. Elkhloufi, M. Biesemans, R. Willem, J. Meunierpiret, Polyhedron 11 (1992) 1861-1868.

[19] S. Tabassum, S. Yadav, Inorg. Chim. Acta 423, Part B (2014) 204-214.

[20] A. Pellerito, T. Fiore, A.M. Giuliani, F. Maggio, L. Pellerito, C. Mansueto, Appl. Organomet. Chem. 11 (1997) 707-719.

[21] M.A. Costa, L. Pellerito, V. Izzo, T. Fiore, C. Pellerito, M. Melis, M.T. Musmeci, G. Barbieri, Cancer Lett. 238 (2006) 284-294.

[22] M.A. Costa, L. Gulino, L. Pellerito, T. Fiore, C. Pellerito, G. Barbieri, Oncol. Rep. 21 (2009) 593-599.

[23] M.A. Costa, F. Zito, M.R. Emma, L. Pellerito, T. Fiore, C. Pellerito, G. Barbieri, Int. J. Oncol. 38 (2011) 693-700.

[24] G.Y. Han, P. Yang, J. Inorg. Biochem. 91 (2002) 230-236.

[25] M.G. Mirisola, A. Pellerito, T. Fiore, G.C. Stocco, L. Pellerito, A. Cestelli, I. DiLiegro, Appl. Organomet. Chem. 11 (1997) 757-757.

[26] C. Mansueto, E. Puccia, F. Maggio, R. Di Stefano, T. Fiore, C. Pellerito, F. Triolo, L. Pellerito, Appl. Organomet. Chem. 14 (2000) 229-235.

[27] A. Mazzaglia, M.L. Bondi, A. Scala, F. Zito, G. Barbieri, F. Crea, G. Vianelli, P. Mineo, T. Fiore, C. Pellerito, L. Pellerito, M.A. Costa, Biomacromolecules 14 (2013) 3820-3829.

[28] T. Biver, D. Lombardi, F. Secco, M.R. Tine, M. Venturini, A. Bencini, A. Bianchi, B. Valtancoli, Dalton Trans. (2006) 1524-1533.

[29] R.F. Pasternack, P.R. Huber, P. Boyd, G. Engasser, L. Francesconi, E. Gibbs, P. Fasella, G. Cerio Venturo, L.d. Hinds, J. Am. Chem. Soc. 94 (1972) 4511-4517.

[30] J.V. Hollingsworth, A.J. Richard, M.G.a.H. Vicente, P.S. Russo, Biomacromolecules 13 (2012) 60-72.

[31] S.M. Andrade, S.M.B. Costa, Ann. N. Y. Acad. Sci. 1130 (2008) 305-313.

[32] O. Ohno, Y. Kaizu, H. Kobayashi, J. Chem. Phys. 99 (1993) 4128-4139.

[33] N.C. Maiti, M. Ravikanth, S. Mazumdar, N. Periasamy, J. Phys. Chem. 99 (1995) 17192-17197.

[34] T. Gensch, S.E. Braslavsky, J. Phys. Chem. B 101 (1997) 101-108.

[35] R.F. Araujo, C.J.R. Silva, M.C. Paiva, M.M. Franco, M.F. Proenca, RSC Adv. 3 (2013) 24535-24542.

[36] T. Biver, A. Boggioni, F. Secco, E. Turriani, M. Venturini, S. Yarnaoluk, Arch. Biochem. Biophys. 465 (2007) 90-100.

[37] R.F. Pasternack, N. Sutin, D.H. Turner, J. Am. Chem. Soc. 98 (1976) 1908-1913.

[38] A. Farajtabar, F. Gharib, P. Jamaat, N. Safari, J. Chem. Eng. Data 53 (2008) 350-354. 
[39] T. Biver, A. De Biasi, F. Secco, M. Venturini, S. Yarmoluk, Biophys. J. 89 (2005) 374-383.

[40] R.F. Pasternack, E.J. Gibbs, Met. lons Biol. Syst. 33 (1996) 367-397.

[41] T. Biver, Appl. Spectrosc. Rev. 47 (2012) 272-325.

[42] S. Aydinoglu, T. Biver, F. Secco, M. Venturini, Int. J. Chem. Kinet. 42 (2010) 79-89.

[43] T. Biver, N. Eltugral, A. Pucci, G. Ruggeri, A. Schena, F. Secco, M. Venturini, Dalton Trans. 40 (2011) 4190-4199.

[44] N. Busto, J. Valladolid, C. Aliende, F.A. Jalon, B.R. Manzano, A.M. Rodriguez, J.F. Gaspar, C. Martins, T. Biver, G. Espino, J.M. Leal, B. Garcia, Chem-Asian J. 7 (2012) 788-801.

[45] H.A. Benesi, J.H. Hildebrand, J. Am. Chem. Soc. 71 (1949) 2703-2707.

[46] S. Bhattacharya, G. Mandal, T. Ganguly, J. Photochem. Photobiol. B-Biol 101 (2010) 89-96.

[47] S.G. Jiang, M.H. Liu, J. Phys. Chem. B 108 (2004) 2880-2884.

[48] R. Barbieri, G. Alonzo, R.H. Herber, Dalton Trans. (1987) 789-794.

[49] J.B. Chaires, Arch. Biochem. Biophys. 453 (2006) 26-31.

[50] H.J. Schneider, M.X. Wang, J Org Chem 59 (1994) 7473-7478.

[51] S. Tabassum, S. Mathur, F. Arjmand, K. Mishra, K. Banerjee, Metallomics 4 (2012) 205-217.

[52] P. Yang, M.L. Guo, Coordin Chem Rev 185-6 (1999) 189-211.

[53] F. Arjmand, I. Yousuf, J. Organomet. Chem. 743 (2013) 55-62.

[54] M. Boualam, R. Willem, M. Biesemans, M. Gielen, Appl. Organomet. Chem. 5 (1991) 497-506.

[55] H. Jankovics, L. Nagy, Z. Kele, C. Pettinari, P. D'Agati, C. Mansueto, C. Pellerito, L. Pellerito, J. Organomet. Chem. 668 (2003) 129-139. 


\section{TABLES}

Table 1. Equilibrium constants $(\mathrm{K})$ from spectrophotometric titrations for dye binding to a DNA isolated site for different systems analysed; $\mathrm{pH} 7.0, \mathrm{NaCl} 0.1 \mathrm{M}, \mathrm{NaCac} 0.01 \mathrm{M}$.

\begin{tabular}{lll}
\hline Porphyrin dye & $\mathrm{K}$ at $25{ }^{\circ} \mathrm{C}\left(\mathrm{M}^{-1}\right)$ & $\mathrm{K}$ at $40{ }^{\circ} \mathrm{C}\left(\mathrm{M}^{-1}\right)$ \\
\hline $\mathrm{TPPS}^{4-}$ & very high & very high \\
$\left(\mathrm{Me}_{2} \mathrm{Sn}\right)_{2} \mathrm{TPPS}$ & very high & $(2.4 \pm 0.5) \times 10^{6}$ \\
$\left(\mathrm{Bu}{ }_{2} \mathrm{Sn}\right)_{2} \mathrm{TPPS}$ & $(1.2 \pm 0.1) \times 10^{6}$ & $(4.3 \pm 0.3) \times 10^{5}$ \\
$\left(\mathrm{Me}_{3} \mathrm{Sn}\right)_{4} \mathrm{TPPS}$ & $(9.0 \pm 0.2) \times 10^{5}$ & $(4.5 \pm 0.3) \times 10^{5}$ \\
$\left(\mathrm{Bu}{ }_{3} \mathrm{Sn}\right)_{4} \mathrm{TPPS}$ & $(7.2 \pm 0.6) \times 10^{5}$ & $(3.7 \pm 0.1) \times 10^{5}$ \\
\hline
\end{tabular}

Table 2. Reduction of the Stern-Volmer constant, $\mathrm{K}_{\mathrm{SV}}$, in the presence of DNA for the different organotin(IV) dyes studied. $\mathrm{F}^{\circ} / \mathrm{F}=1+\mathrm{K}_{\mathrm{SV}}\left[\mathrm{I}^{-}\right] ; \mathrm{K}_{\mathrm{SV}}{ }^{\circ}$ is the Stern-Volmer constant for the dye alone, $\mathrm{K}_{\mathrm{SV}}{ }^{\mathrm{DNA}}$ is the Stern-Volmer constant in the presence of DNA excess, $\%=100^{*}\left(\mathrm{~K}_{\mathrm{SV}^{\circ}}\right.$ $\left.\mathrm{K}_{\mathrm{SV}}{ }^{\mathrm{DNA}}\right) / \mathrm{K}_{\mathrm{SV}}{ }^{\circ}, \mathrm{pH} 7.0, \mathrm{NaCl} 0.1 \mathrm{M}, \mathrm{NaCac} 0.01 \mathrm{M}$.

\begin{tabular}{lccc}
\hline Porphyrin dye & $\mathrm{K}_{\mathrm{SV}^{\circ}}\left(\mathrm{M}^{-1}\right)$ & $\mathrm{K}_{\mathrm{SV}}{ }^{\mathrm{DNA}}\left(\mathrm{M}^{-1}\right)$ & $\%$ \\
\hline$\left(\mathrm{Me}_{2} \mathrm{Sn}\right)_{2} \mathrm{TPPS}$ & 20.4 & 20.2 & 1.0 \\
$\left(\mathrm{Bu}_{2} \mathrm{Sn}\right)_{2} \mathrm{TPPS}$ & 21.8 & 20.6 & 5.5 \\
$\left(\mathrm{Me}_{3} \mathrm{Sn}\right)_{4} \mathrm{TPPS}$ & 19.9 & 19.0 & 4.5 \\
$\left(\mathrm{Bu}_{3} \mathrm{Sn}\right)_{4} \mathrm{TPPS}$ & 22.3 & 20.5 & 8.1 \\
\hline
\end{tabular}




\section{FIGURE LEGENDS}

Fig. 1. Schematic representation of $\left(\mathrm{Bu}_{3} \mathrm{Sn}\right)_{4} \mathrm{TPPS}$ structure; * indicate the protonation sites at the immine-nitrogen.

Fig. 2. UV-vis analysis of $\left(\mathrm{Bu}_{3} \mathrm{Sn}\right)_{4} \mathrm{TPPS}$ immine-nitrogen protonation. (A) Absorbance spectra at different $\mathrm{HCl}$ content, $\mathrm{C}_{\mathrm{D}}=5.0 \times 10^{-7} \mathrm{M}, \mathrm{I}=0.1 \mathrm{M}(\mathrm{NaCl}) ; \mathrm{T}=25.0^{\circ} \mathrm{C},(\ldots) \mathrm{pH}=6.5,(-) \mathrm{pH}=3.9$, $(--) \mathrm{pH}=2.5$ (inset: $\mathrm{Q}$ bands); (B) titration curve at $435 \mathrm{~nm}$ (inset: system speciation with $\mathrm{pK}_{\mathrm{A} 1}=$ $\left.\mathrm{pK}_{\mathrm{A} 2}=4.05\right)$.

Fig. 3. A) Absorbance spectra of $\left(\mathrm{Bu}_{3} \mathrm{Sn}\right)_{4} \mathrm{TPPS}$ for $\mathrm{C}_{\mathrm{D}}=0$ to $4.0 \times 10^{-6} \mathrm{M}$ and $\left.\mathrm{B}\right)$ absorbance ratio plot; $\mathrm{pH} 7.0, \mathrm{NaCl} 0.1 \mathrm{M}, \mathrm{NaCac} 0.01 \mathrm{M}, \mathrm{T}=25.0^{\circ} \mathrm{C}, \mathrm{A}_{0}=$ absorbance at the maximum $(413 \mathrm{~nm})$, $\mathrm{A}_{1}=$ absorbance at $393 \mathrm{~nm}$, in $(\mathrm{B})(\mathrm{Bu} 3 \mathrm{Sn})_{4} \mathrm{TPPS}=$ open squares, $\left(\mathrm{Me}_{2} \mathrm{Sn}\right)_{2} \mathrm{TPPS}=$ triangles, $\mathrm{TPPS}^{4-}=$ circles, line to drive the eye.

Fig. 4. (A) Fluorescence spectra of the $\left(\mathrm{Bu}_{3} \mathrm{Sn}\right)_{4} \mathrm{TPPS} / \mathrm{DNA}$ system at $\mathrm{C}_{\mathrm{D}}=0.30 \mu \mathrm{M}$ and increasing amounts of DNA $\left(\mathrm{C}_{\mathrm{P}}\right.$ from $0\left[\cdots \cdot{ }^{\circ}\right.$ to $\left.34 \mu \mathrm{M}[---]\right)$ and $(\mathrm{B})$ relevant binding isotherm at $\lambda_{\mathrm{em}}=640$ nm. I $=0.11 \mathrm{M}(\mathrm{NaCl} 0.1 \mathrm{M}, \mathrm{NaCac} 0.01 \mathrm{M}) ; \mathrm{pH}=7.0 ; \mathrm{T}=25.0^{\circ} \mathrm{C}, \lambda_{\text {exc }}=410 \mathrm{~nm}$.

Fig. 5. (A) Absorbance spectra variation for $\left(\mathrm{Bu}_{3} \mathrm{Sn}\right)_{4}$ TPPS upon addition of increasing amounts of DNA and (B) relevant binding isotherm at $413 \mathrm{~nm} ; \mathrm{C}_{\mathrm{D}}=0.20 \mu \mathrm{M}, \mathrm{C}_{\mathrm{P}}=0(\ldots)$ to $12 \mu \mathrm{M}(---), \mathrm{pH}$ 7.0, $\mathrm{NaCl} 0.1 \mathrm{M}, \mathrm{NaCac} 0.01 \mathrm{M}, \mathrm{T}=25.0^{\circ} \mathrm{C}$.

Fig. 6. Analysis according to equation (2) of the binding isotherms from absorbance titration data for the $\left(\mathrm{Bu}_{2} \mathrm{Sn}\right)_{2}$ TPPS/DNA system $(\mathrm{A})$ and the $\left(\mathrm{Bu}_{3} \mathrm{Sn}\right)_{4}$ TPPS/DNA system $(\mathrm{B}) . \mathrm{C}_{\mathrm{D}}=0.2 \mu \mathrm{M}(\mathrm{A})$ and $0.20 \mu \mathrm{M}(\mathrm{B}), \mathrm{pH} 7.0, \mathrm{NaCl} 0.1 \mathrm{M}, \mathrm{NaCac} 0.01 \mathrm{M}, \lambda=413 \mathrm{~nm}, \mathrm{~T}=25.0^{\circ} \mathrm{C}$.

Fig. 7. Relative viscosity plots for the different dye/DNA systems as a function of the $C_{D} / C_{P}$ ratio. $\mathrm{C}_{\mathrm{P}}=2.29 \times 10^{-4} \mathrm{M}, \mathrm{TPPS}^{4-}$ stars, $\left(\mathrm{Me}_{2} \mathrm{Sn}\right)_{2} \mathrm{TPPS} / \mathrm{DNA}$ open circles, $\left(\mathrm{Bu}_{2} \mathrm{Sn}\right)_{2} \mathrm{TPPS} / \mathrm{DNA}$ open triangles, $\left(\mathrm{Me}_{3} \mathrm{Sn}\right)_{4} \mathrm{TPPS} / \mathrm{DNA}$ full circles, $\left(\mathrm{Bu}_{3} \mathrm{Sn}\right)_{4}$ TPPS/DNA full triangles; $\mathrm{NaCl} 0.1 \mathrm{M}, \mathrm{NaCac}$ $0.01 \mathrm{M}, \mathrm{pH}=7.0, \mathrm{~T}=40.0^{\circ} \mathrm{C}$. 
Fig. 1

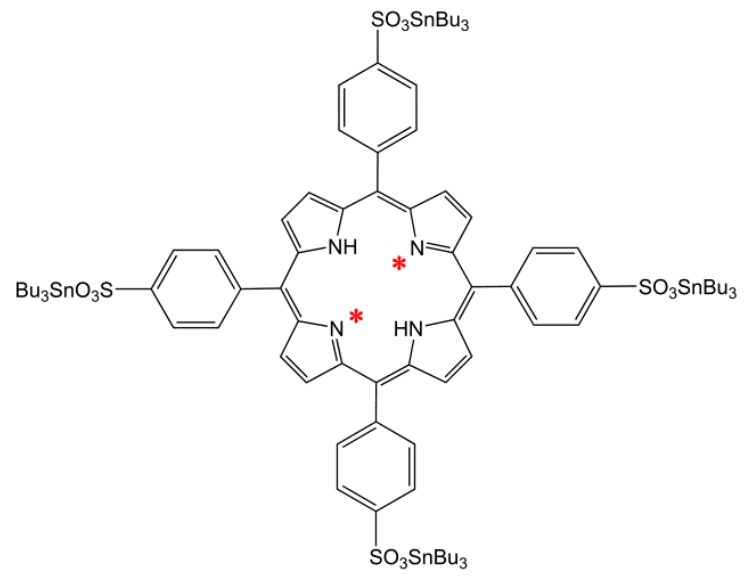

Fig. 2

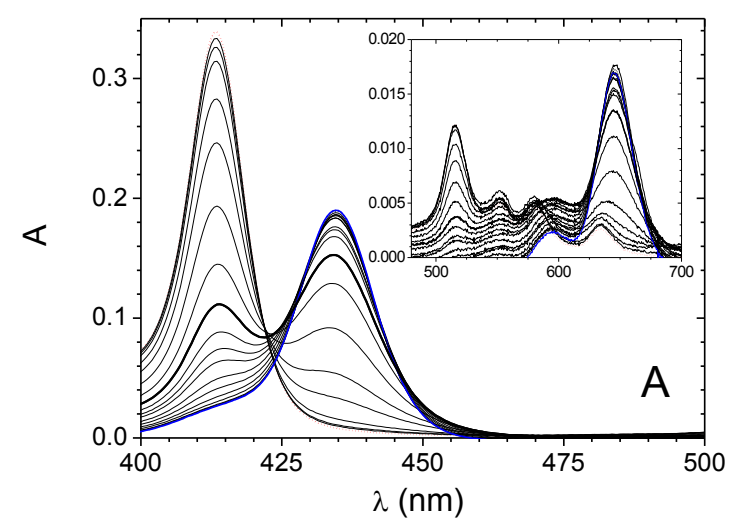

Fig. 3

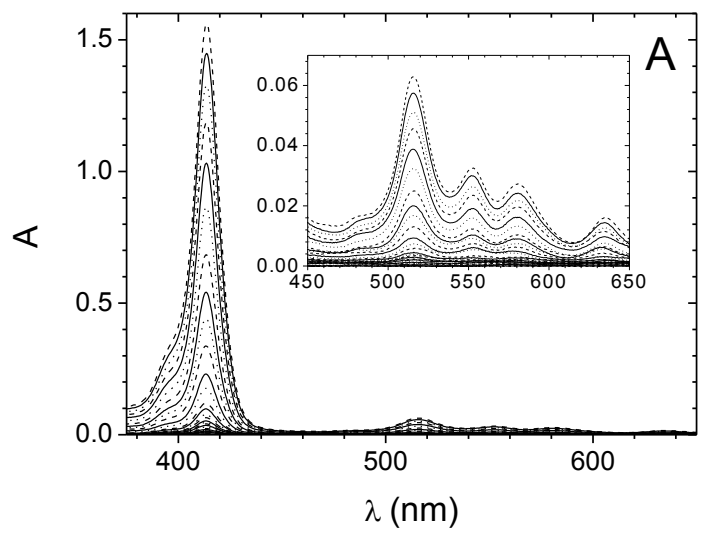

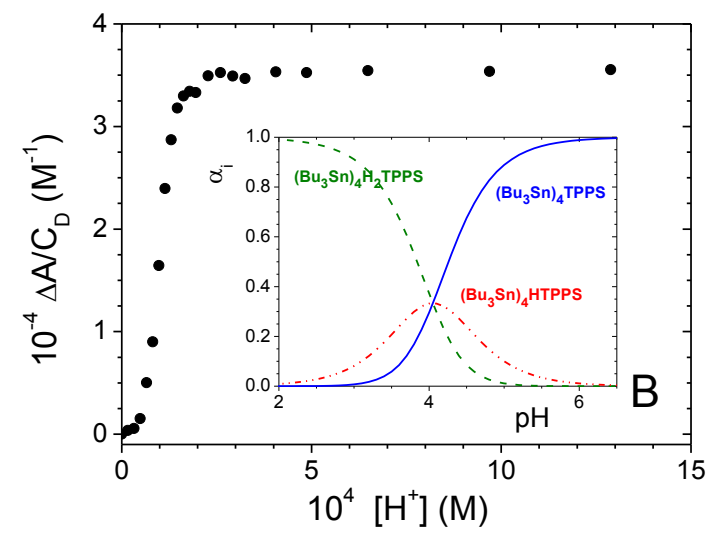

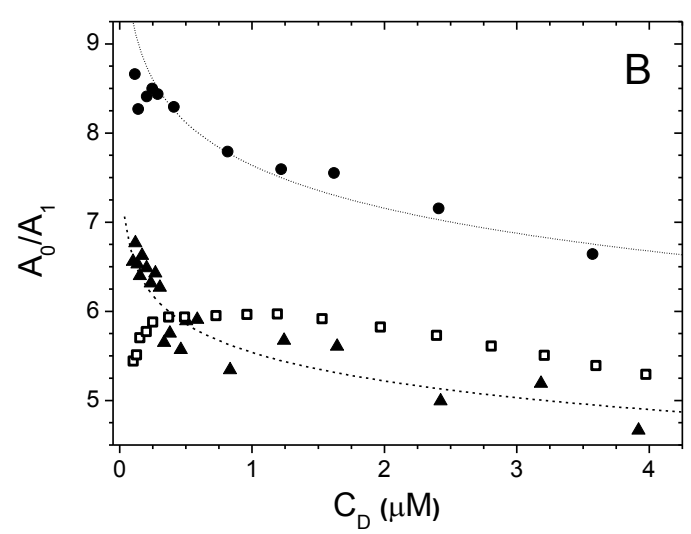


Fig. 4
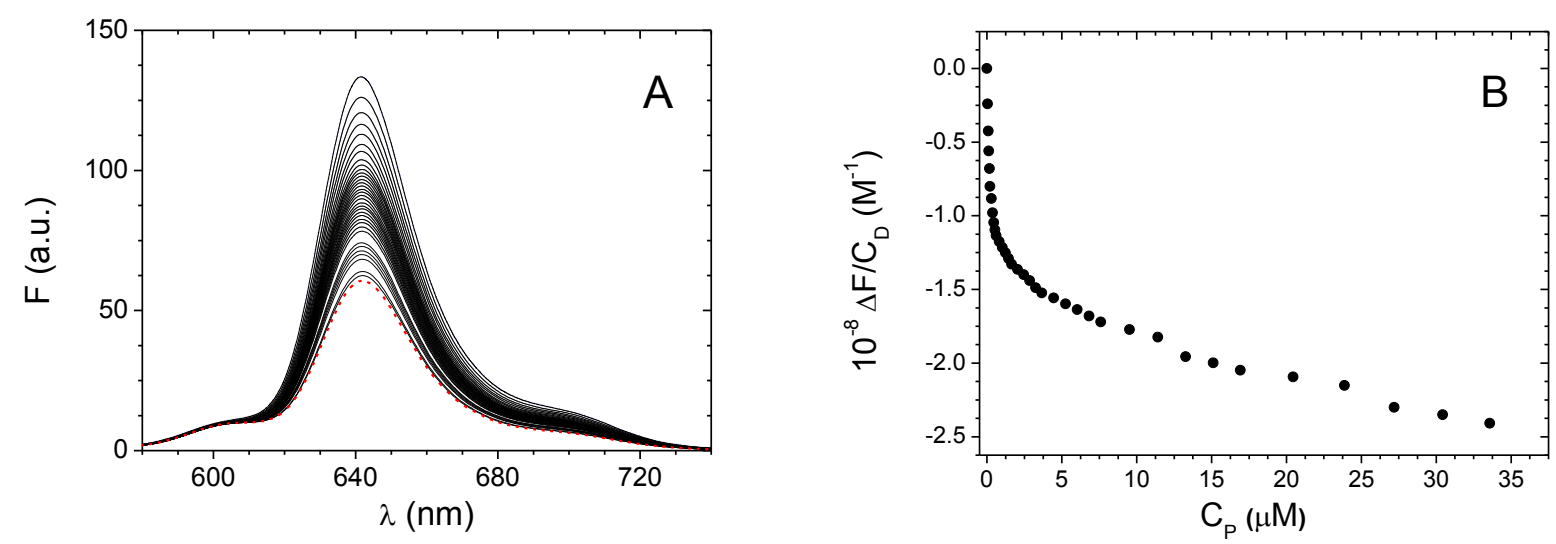

Fig. 5
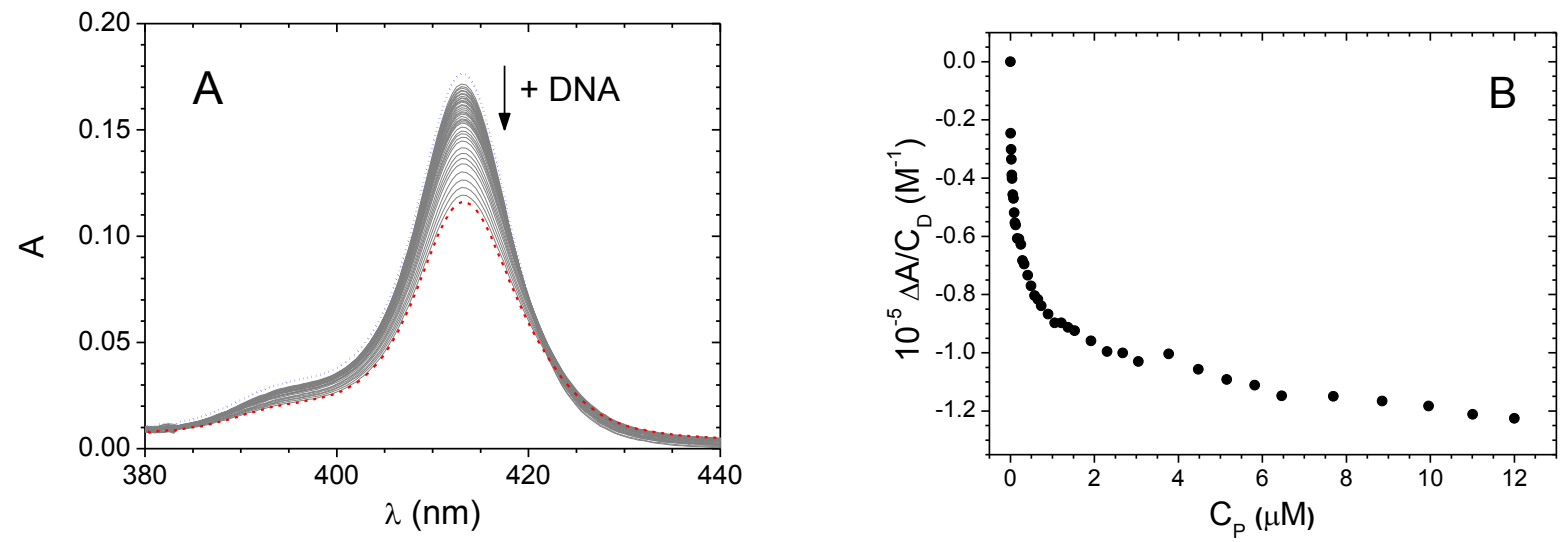

Fig. 6
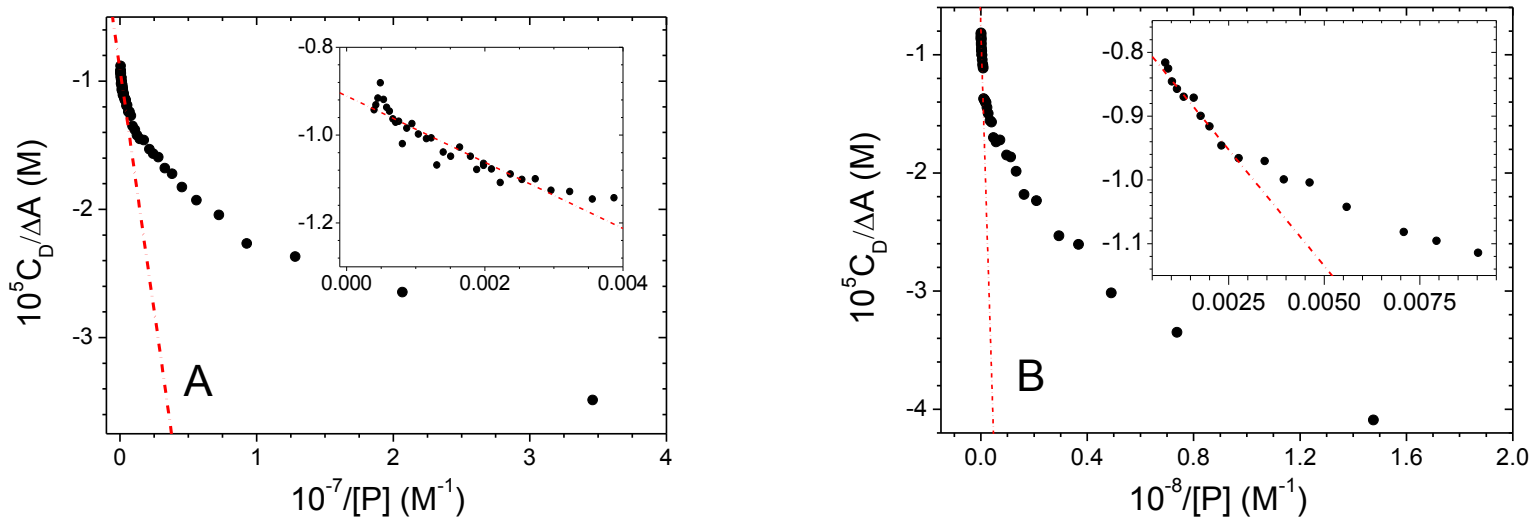
Fig. 7

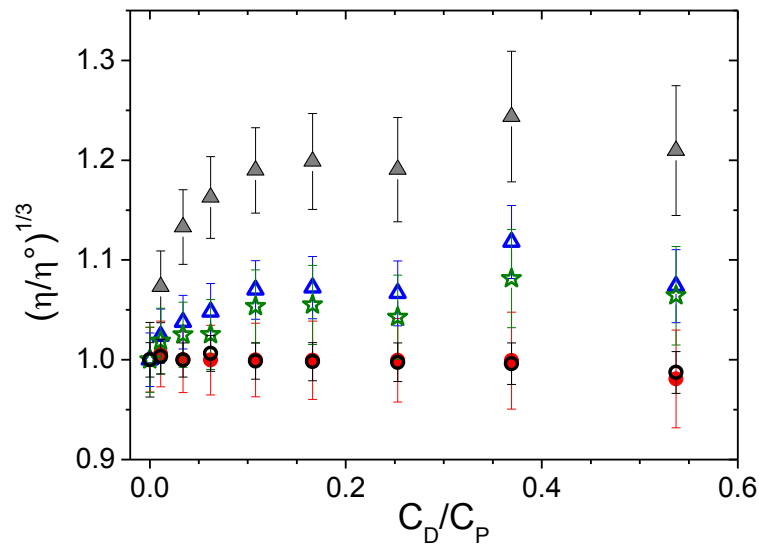


Supplementary Information for Publication Online
Click here to download Supplementary Information for Publication Online: SI-R1.pdf

Supplementary Information for Publication Online
Click here to download Supplementary Information for Publication Online: SI-R1.pdf Cliti

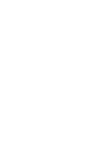

(2)

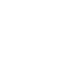

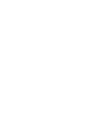

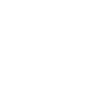

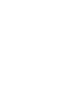

(

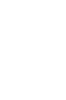

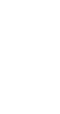

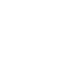
.

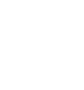

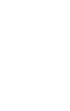
$\sqrt{20}$ $\sqrt{20}$ $x^{2}$ (

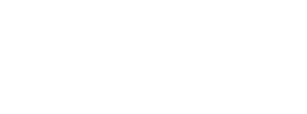
.

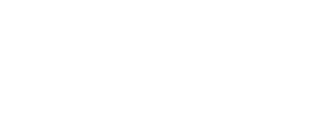
. . . . . . . . . . . .

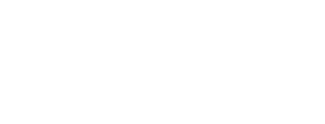
(1) (1) 